Citation: R. Blundell, M. Arreguin, A. Eskalen (2021) In vitro evaluation of grapevine endophytes, epiphytes and sap micro-organisms for potential use to control grapevine trunk disease pathogens. Phytopathologia Mediterranea 60(3): 535-548. doi: 10.36253/ phyto-12500

Accepted: September 30, 2021

Published: December 30, 2021

Copyright: (c) 2021 R. Blundell, M. Arreguin, A. Eskalen. This is an open access, peer-reviewed article published by Firenze University Press (http:// www.fupress.com/pm) and distributed under the terms of the Creative Commons Attribution License, which permits unrestricted use, distribution, and reproduction in any medium, provided the original author and source are credited.

Data Availability Statement: All relevant data are within the paper and its Supporting Information files.

Competing Interests: The Author(s) declare(s) no conflict of interest.

Editor: Lizel Mostert, Faculty of AgriSciences, Stellenbosch, South Africa.
Research Papers

\section{In vitro evaluation of grapevine endophytes, epiphytes and sap micro-organisms for potential use to control grapevine trunk disease pathogens}

\author{
Robert BLUNDELL, Molly ARREGUIN, AKIF ESKALEN* \\ Department of Plant Pathology, University of California Davis, One Shields Avenue, \\ Davis, CA, 95616-8751, USA \\ *Corresponding author. E-mail: aeskalen@ucdavis.edu
}

Summary. Grapevine trunk diseases (GTDs) threaten the economic sustainability of viticulture, causing reductions of yield and quality of grapes. Biological control is a promising sustainable alternative to cultural and chemical methods to mitigate the effects of pathogens causing GTDs, including Botryosphaeria dieback, Eutypa dieback and Esca. This study aimed to identify naturally occurring potential biological control agents from grapevine sap, cane and pith tissues, and evaluate their in vitro antagonistic activity against selected fungal GTD pathogens. Bacterial and fungal isolates were preliminarily screened in dual culture assays to determine their antifungal activity against Neofusicoccum parvum and Eutypa lata. Among the fungal isolates, Trichoderma spp. inhibited mycelium growth of E. lata by up to $64 \%$ and of $N$. parvum by up to $73 \%$, with overgrowth and growth cessation being the likely antagonistic mechanisms. Among the bacterial isolates, Bacillus spp. inhibited mycelium growth of E. lata by up to $20 \%$ and of N. parvum by up to $40 \%$. Selected antagonistic isolates of Trichoderma, Bacillus and Aureobasidium spp. were subjected to further dual culture antifungal analyses against Diplodia seriata and Diaporthe ampelina, with Trichoderma isolates consistently causing the greatest inhibition. Volatile organic compound antifungal analyses showed that these Trichoderma isolates inhibited mycelium growth of N. parvum (20\% inhibition), E. lata (61\% inhibition) and Dia. ampelina (71\% inhibition). Multilocus sequence analyses revealed that the Trichoderma isolates were most closely related to Trichoderma asperellum and Trichoderma hamatum. This study had identified grapevine sap as a novel source of potential biological control agents for control of GTDs. Further testing will be necessary to fully characterize modes of antagonism of these microorganisms, and assess their efficacy for pruning wound protection in planta.

Keywords. Biological control, endophytes, microbial antagonism, antifungal.

\title{
INTRODUCTION
}

Fungal diseases are major biotic threats to future economic sustainability of table and wine grape production. Grapevine trunk diseases (GTDs) are prevalent in most viticulture regions causing significant yield and quality 
reductions, and increasing crop management costs for cultural and chemical disease management (Siebert et al., 2001; Gubler et al., 2005; Úrbez-Torres et al., 2006; Bertsch et al., 2013; Kaplan et al., 2016). GTDs lead to premature decline and dieback of grapevines and are caused by complexes of several taxonomically unrelated Ascomycetes. Botryosphaeria dieback, also known as Black Dead Arm or 'Bot Canker', is one of the most severe GTDs and is currently associated with 26 botryosphaeriaceous taxa including Botryosphaeria, Diplodia, Dothriorella, Lapsiodiplodia, Neofusicoccum, Neoscytalidium, Phaeobotryosphaeria, and Spencermartinsia (Úrbez-Torres. 2011; Pitt et al., 2013; Rolshausen et al., 2013; Pitt et al., 2015; Yang et al., 2017). Another severe GTD is Eutypa dieback, caused by 24 species of Diatrypaceae, with the most virulent and common being Eutypa lata (Trouillas et al., 2010; Pitt et al., 2013; Luque et al., 2014; Rolshausen et al., 2014). Esca and Phomopsis dieback also comprise the GTD complex, and are of worldwide economic importance (Munkvold et al., 1994). GTDs can occur simultaneously, though severity may differ among regions (Mugnai et al., 1999; Pascoe and Cottral, 2000; Halleen et al., 2003; Gubler et al., 2005). Characteristic symptoms of Botryosphaeria and Eutypa dieback are development of wedge-shaped cankers in infected grapevine trunks and cordons. From the infection sites, which are often pruning wounds, the fungi will grow downwards occupying vascular elements and adjacent cells. When affected vineyards are no longer economically sustainable, growers face no alternative other than replanting (Gramaje et al., 2018). GTDs can also be found in dormant wood cuttings and young grafted plants, and thus spread to grapevines during plant propagation processes (Waite and Morton, 2007; Aroca et al., 2010; Gramaje and Armengol, 2011; Billones-Baaijens et al., 2013).

Management of GTDs is difficult and influenced by the specific disease and/or pathogens involved, but a variety of preventative methods have been studied and implemented. These include cultural practices such as double pruning and application of fungicides (Bertsch et al., 2013). However, these methods have highly variable efficacy, may not be environmentally sustainable, and can be costly (Zanzotto and Morroni, 2016). A promising approach is the use of biological control agents (BCAs) to control pathogens causing GTDs. This utilizes naturally occurring micro-organisms to suppress pests and pathogens (Heimpel and Mills, 2017; MartinezDiz et al., 2020). Grapevines can be colonized by many micro-organisms that can reside intercellularly or intracellularly as endophytes (West et al., 2010; Gilbert et al., 2014), or they can colonize surfaces of grapevine organs, especially leaves, as epiphytes (Hardoim et al., 2015; Bruisson et al., 2019). Endophytes have been shown to be valuable potential BCAs, as they have been associated with most plant species, and most are non-pathogenic bacteria or fungi that asymptomatically colonize their hosts (Strobel and Daisy. 2003).

Since about 2000, more than 40 BCAs have been isolated, identified and tested against the pathogens responsible for the GTD complex, and while the majority of cultured endophytes do not exhibit inhibitory activity, some Trichoderma spp. and Bacillus spp. have been highly efficient in protecting pruning wounds against various GTD pathogens in vitro, and in greenhouse and field trials (Schmidt et al., 2001; Di Marco et al., 2002; 2004; John et al., 2008; Halleen et al., 2010; Kotze et al., 2011; Rezgui et al., 2016; Mondello et al., 2018; Martinez-Diz et al., 2020) Several successful efforts have also been made to commercialize these organisms as BCAs (Otoguro and Suzuki, 2018). Trichoderma spp. can stimulate plant growth and suppress pathogens by direct competition for nutrients and space, exhibit mycoparasitism and antibiosis, and/or induce systemic resistance (John et al., 2005; Harman, 2006; Mukherjee et al., 2013). Bacillus spp. can antagonize GTDs through antibiotic production, competition for nutrients, and/ or activation of host defense responses (Choudhary and Johri 2009; Cawoy et al., 2011).

There have been no published reports of evaluation of grapevine sap inhabiting microbes for their antifungal activity against GTD pathogens. The majority of antagonistic endophyte studies in relation to GTDs have sourced microbes from grapevine bark or roots. The present study aimed to exploit this knowledge gap by isolating microbes from grapevine sap, both immediately after making fresh pruning cuts and $7 \mathrm{~d}$ later, and evaluating their in vitro antagonistic activity against several pathogens responsible for GTDs. Isolations of potential antagonists were also made from grapevine pith and cane tissues.

\section{MATERIALS AND METHODS}

\section{Isolation of potential biocontrol organisms from grapevine}

All microbial sampling was performed at the Plant Pathology Fieldhouse Facility, University of California, Davis in Yolo County $\left(38^{\circ} 31^{\prime} 24.1^{\prime \prime} \mathrm{N}, 121^{\circ} 45^{\prime} 43.3^{\prime \prime} \mathrm{W}\right)$ from (Vitis vinifera, Cultivar Chenin Blanc - 10-yrsold) in March 2019 prior to any standard pruning. A total of ten randomly selected apparently 'healthy' vines were used in this study, with samples taken from four randomly pruned spurs per vine. For collection of sap 
exudate, the cut points of 1-year-old lignified spurs were sprayed with $70 \%$ ethanol for surface sterilization to avoid contamination, and once dry, a horizontal pruning cut was made in each spur with sterile pruning shears. A $100 \mu \mathrm{L}$ sample of sap exudate was immediately collected from the bleeding wound with a pipette and stored on ice. A $20 \mu \mathrm{L}$ aliquot of sap exudate from each spur was later spread by a sterile glass rod onto each of petri plates containing either potato dextrose agar amended with $100 \mathrm{mg} \mathrm{L}^{-1}$ tetracycline (PDA-T) or nutrient agar (NA). Growing fungal or bacterial cultures were subcultured for in vitro screening and molecular identifications. Epiphytic microbes were sampled by scraping dry sap from the pruning surfaces $7 \mathrm{~d}$ after the initial cut from the same grapevine canes, and the samples were plated as described above. After incubation at $25^{\circ} \mathrm{C}$ for approx. $7 \mathrm{~d}$, sub-cultures of all growing microbes were made to fresh PDA-T or NA.

Grapevine endophytes were also isolated in September 2019 from the same vineyard, from untreated canes used in a pruning wound protection trial. The canes were each split longitudinally, and isolations were made from the exposed wood and pith tissues. A total of ten canes were used and three pieces of tissue and three pieces of pith were collected from each cane. These tissue pieces were then plated on PDA-T and NA plates. The plates were incubated at $25^{\circ} \mathrm{C}$ for approx. $7 \mathrm{~d}$ before subcultures were made of growing isolates.

\section{Extractions of genomic DNA}

Genomic DNA was extracted from fungi by scraping mycelium from each 1-week-old isolate subculture, and adding this to a $2 \mathrm{~mL}$ capacity tube containing 300 $\mathrm{mL}$ of Nuclei Lysis Solution and $1 \mathrm{~mm}$ diam. glass beads (bioSpec Products). Mycelium was homogenized for 40 $\mathrm{s}$ at $6 \mathrm{~m} \mathrm{~s}^{-1}$ in a FastPrep-24 $5 \mathrm{G}$ bead beating grinder and lysis system (MP Biomedicals). Genomic DNA was extracted using a DNA extraction kit (Wizard Genomic DNA Purification Kit; Promega Corporation). Genomic DNA was extracted from each 1-week-old bacterial sub culture by collecting a loop of bacteria with a sterile pipette tip and inoculating a $0.2 \mathrm{~mL}$ capacity PCR tube containing $15 \mathrm{~mL}$ of Molecular Grade Water culturing for $15 \mathrm{~min}$ at $95^{\circ} \mathrm{C}$ in a thermal cycler.

PCR amplification and sequencing of fungal ITS, TEF-1a and b1-tubulin genes

The internal transcribed spacer (ITS) region of the ribosomal RNA ( $r R N A$ ) gene was amplified using the primers, ITS1 and ITS4 (White et al., 1990). The translation elongation factor 1 alpha gene (TEF-1a) was amplified using the primers, EF1-728F and EF1-968R (Carbone and Kohn, 1999). The beta tubulin gene (Bt) was amplified using the primers, Bt2a and Bt2b (Glass and Donaldson, 1995).

PCR amplification and sequencing of Bacterial 16S rRNA, puH and rpoB genes

The 16S rRNA gene was amplified using the primers $16 \mathrm{~S}$ U1 and 16S U2 (Lu et al., 2000). The purine biosynthesis gene was amplified using the primers, purH-70f and purH-1013r (Rooney et al., 2009). The RNA polymerase subunit $\mathrm{B}(r p o B)$ gene was amplified using the primers, rpoB-229f and rpoB-3354Rr (Rooney et al., 2009).

\section{PCR assays}

PCR assays were each carried out in a final volume of $25 \mathrm{~mL}$, in a reaction mixture containing $0 \mathrm{mM}$ Tris- $\mathrm{HCl}$ (pH 8.8), $50 \mathrm{mM} \mathrm{KCl}, 3 \mathrm{mM} \mathrm{MgCl} 2,0.2 \mathrm{mM}$ of each dNTP, $1.0 \mathrm{mM}$ of each primer and 1 unit of Go Taq polymerase (Promega Corporation). Primers and excess nucleotides were removed from the amplified DNA using a PCR clean-up kit (EXO SAP; New England BioLabs), and DNA was quantified using a QuantiFluor dsDNA System (Promega Corporation). Purified PCR samples were sent to Quintarabio, Hayward for Sanger Sequencing. Sequence chromatograms were analyzed, and the sequences were assembled using Sequencher version 5.4.6. Alignment was performed with Clustal W. Phylogenetic analysis was carried out with Mega X using the maximum composite likelihood model for estimating genetic differences. A phylogenetic tree was obtained using the neighbour-joining method with 1000 bootstrap replicates.

\section{Dual culture assays}

All fungal and bacterial isolates were tested in in vitro dual culture assays against the GTD pathogens $N$. parvum and E. lata. Fresh subcultures were made from each isolate and incubated at $25^{\circ} \mathrm{C}$ for 1 week on PDA$\mathrm{T}$ plates for fungal isolates and PDA plates for bacterial isolates for the assay. A $5 \mathrm{~mm}$ diam. plug from each isolate culture was then placed $1 \mathrm{~cm}$ from the edge of a 100 $\times 15 \mathrm{~mm}$ plate, and a $5 \mathrm{~mm}$ diam. plug of 1-week-old $N$. parvum or E. lata agar culture was placed $1 \mathrm{~cm}$ from the opposite edge of the plate. Plates with only the patho- 
gens were used as experimental controls. Neofusicoccum parvum assays were incubated at $25^{\circ} \mathrm{C}$ for $4 \mathrm{~d}$ before the percentage of pathogen inhibition was recorded. The E. lata assays were incubated at $25^{\circ} \mathrm{C}$ for $14 \mathrm{~d}$ before being recorded. The percentage of inhibition of pathogen mycelium growth was calculated using the formula of Idris et al. (2007): \% inhibition $=[(\mathrm{C}-\mathrm{T}) / \mathrm{C}] \times 100)$, where $\mathrm{C}$ is the colony radius $(\mathrm{mm})$ of the pathogen when plated by itself and $\mathrm{T}$ is the radius of the pathogen when plated with an isolate. There were a total of ten replicates per isolate in these assays. Representative isolates from each genus exhibiting potential biological control activity against $N$. parvum or E. lata were subsequently tested against the GTD pathogens Diplodia seriata and Diaporthe ampelina using the same assay protocol.

\section{Assays for production of volatile compounds}

Production of antifungal volatile organic compounds (VOCs) was assessed using the two-sealed-base-plates method described by Gotor-Vila et al. (2017), with modifications. Petri dishes $(100 \times 15 \mathrm{~mm})$ were each half filled with PDA-T or PDA, and a $5 \mathrm{~mm}$ diam. mycelium plug of each 1-week-old isolate were placed in the centre of each base plate. A $5 \mathrm{~mm}$ diam. mycelium plug of a pathogen was placed in the centre of another base plate and the two base plates were immediately sealed together using parafilm. Plates with only the pathogen served as experimental controls. Neofusicoccum parvum and D. seriata assays were incubated at $25^{\circ} \mathrm{C}$ for $4 \mathrm{~d}$ before percentage of pathogen inhibition was recorded, and E. lata and Dia. ampeli$n a$ assays were incubated at $25^{\circ} \mathrm{C}$ for $14 \mathrm{~d}$. The percentage inhibition of pathogen mycelium growth was calculated using the formula of Idris et al. (2007) (above). Ten replicates were used for each isolate tested.

\section{Statistical analyses}

Data obtained from the dual culture assays were analyzed using one-way ANOVA, and means were separated using the post hoc Dunnett's test at $P=0.05$.

\section{RESULTS}

Isolation and ITS/16s sequencing of potential biocontrol organisms

Eleven fungal isolates and two bacterial isolates were cultured on growth media from sampled grapevine tissues (Table 1). The majority of isolates were obtained
Table 1. Sources of isolated microorganisms and their ITS/16S identification

\begin{tabular}{|c|c|c|}
\hline Isolate & Source & Genus \\
\hline UCD 8193 & Grapevine cane tissue & $\begin{array}{l}\text { Aureobasidium } \\
\text { (ITS) }\end{array}$ \\
\hline UCD 8248 & Grapevine cane tissue & $\begin{array}{l}\text { Aureobasidium } \\
\text { (ITS) }\end{array}$ \\
\hline UCD 8302 & Grapevine sap, collected immediately & $\begin{array}{l}\text { Aureobasidium } \\
\text { (ITS) }\end{array}$ \\
\hline UCD 8176 & Grapevine cane tissue & $\begin{array}{l}\text { Aureobasidium } \\
\text { (ITS) }\end{array}$ \\
\hline UCD 8174 & Grapevine sap, collected immediately & $\begin{array}{c}\text { Aureobasidium } \\
\text { (ITS) }\end{array}$ \\
\hline UCD 8196 & Grapevine sap, collected immediately & $\begin{array}{l}\text { Aureobasidium } \\
\text { (ITS) }\end{array}$ \\
\hline UCD 8170 & Grapevine sap, collected immediately & $\begin{array}{l}\text { Aureobasidium } \\
\text { (ITS) }\end{array}$ \\
\hline UCD 8344 & Grapevine cane tissue & $\begin{array}{l}\text { Aureobasidium } \\
\text { (ITS) }\end{array}$ \\
\hline UCD 8189 & Grapevine sap, collected immediately & $\begin{array}{l}\text { Aureobasidium } \\
\text { (ITS) }\end{array}$ \\
\hline UCD 8745 & Grapevine sap, collected after 7 days & Bacillus (16S) \\
\hline UCD 8347 & Grapevine cane pith tissue & Bacillus (16S) \\
\hline UCD 8368 & Grapevine cane tissue & $\begin{array}{l}\text { Trichoderma } \\
\text { (ITS) }\end{array}$ \\
\hline UCD 8717 & Grapevine sap, collected after 7 days & $\begin{array}{l}\text { Trichoderma } \\
\text { (ITS) }\end{array}$ \\
\hline
\end{tabular}

from either cane tissue or sap collected immediately after pruning cuts were made. Only two isolates were obtained from sap $7 \mathrm{~d}$ after pruning, and one isolate was obtained from grapevine pith. PCR amplification of the ITS gene, sequencing and BLAST analyses showed that nine of the fungal isolates were Aureobasidium and two were Trichoderma (Table 1). PCR amplification of the $16 \mathrm{~S}$ rRNA, sequencing and BLAST analyses showed that the two bacterial isolates were Bacillus genus (Table 1).

Preliminary screening, dual culture assays with Neofusicoccum parvum and Eutypa lata

The in vitro antagonistic potential of all subcultured bacterial and fungal isolates (Table 1) was initially evaluated against the GTDs pathogens N. parvum and E. lata using dual culture assays. While the majority of isolates did not inhibit mycelium growth of $N$. parvum, two Bacillus spp. isolates (UCD 8745 and UCD 8347) and two Trichoderma isolates (UCD 8368 and UCD 8717) inhibited growth of this pathogen, by $35 \%$ to $64 \%(P \leq$ 0.05; Figure 1A) compared to the $N$. parvum control. When the isolates were tested for antagonistic potential 


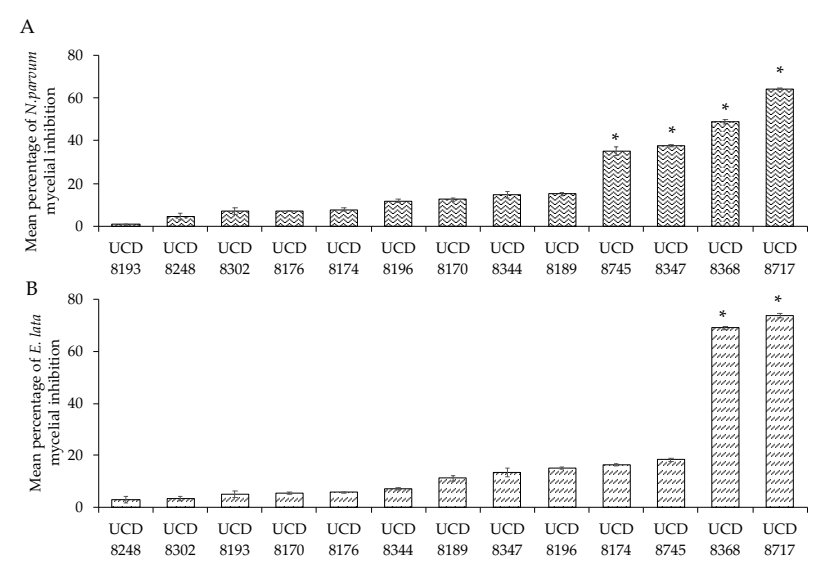

Figure 1. Preliminary in vitro dual culture evaluation of isolated microorganisms' ability to inhibit radial mycelium growth of the grapevine trunk disease pathogens (A) Neofusicoccum parvum and (B) Eutypa lata. Values are means ( \pm standard errors) of ten replicates. ${ }^{*}$ indicates differences compared with experimental controls (Dunnett's test; $P \leq 0.05$ ).

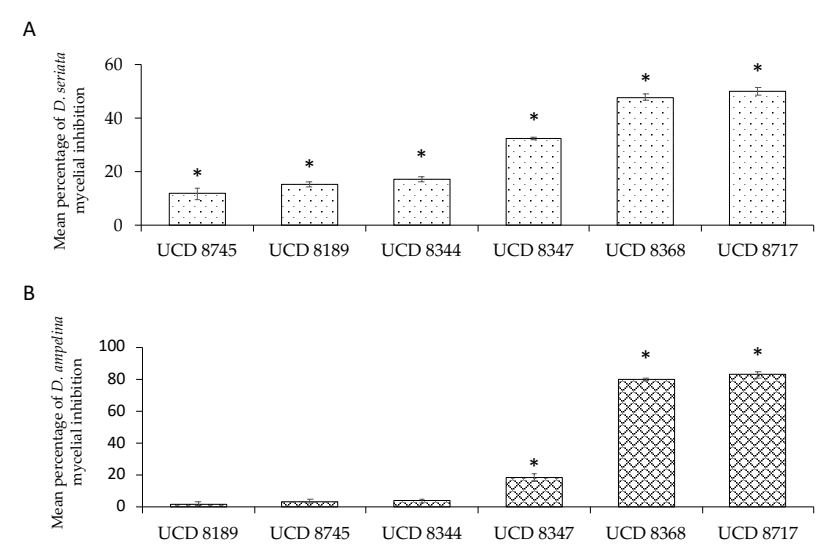

Figure 2. In vitro dual culture evaluation of selected microorganisms' ability to inhibit radial mycelial growth of the grapevine trunk disease pathogens (A) Diplodia seriata and (B) Diaporthe ampelina. Asterisk $\left({ }^{*}\right)$ indicates significant inhibition in comparison with a control (Dunnett's test $P \leq 0.05$ ).

against E. lata, only the Trichoderma isolates UCD 8368 and UCD 8717 radial mycelium growth, with both isolated reducing growth by more than $65 \%(P \leq 0.05$; Figure. $1 \mathrm{~B})$.

Dual culture assays with Diplodia seriata and Diaporthe ampelina

The Trichoderma isolates UCD 8368 and UCD 8717 and Bacillus isolates UCD 8745 and UCD 8347 were further assessed in dual culture assays, as were the
Aureobasidium isolates, UCD 8189 and UCD 8344, to evaluate these genera for suppression of $D$. seriata and Dia. ampelina. All isolates inhibited growth of $D$. seriata by $15 \%$ to $50 \%(P \leq 0.05$; Figure $2 \mathrm{~A})$. Both Trichoderma isolates gave the greatest growth inhibition at approx. $50 \%$ compared to the controls. There was variation between the Bacillus isolates, with UCD 8347 causing approx. 32\% inhibition and UCD 8745 causing approx. 11\% inhibition. The Aureobasidium isolates UCD 8189 and UCD 8344 were similar in their antagonistic activity, causing, respectively, approx. $15 \%$ and $17 \%$ inhibition. When the isolates were tested against Dia. ampeli$n a$, the Trichoderma isolates UCD 8368 and UCD 8717 caused the greatest inhibition, in excess of $80 \%$. The Bacillus isolate UCD 8347 also reduced mycelium radial growth of Dia. ampelina, though to a much lesser extent $(P \leq 0.05$; Figures $2 \mathrm{~B}$ and 3$)$

\section{Assays for volatile organic compounds}

When the isolates were screened against $N$. parvum for antagonistic activity through production of antifungal volatile organic compounds (VOCs), only Bacillus isolate UCD 8347 (approx. 10\% inhibition) and Trichoderma isolate UCD 8368 (approx. 20\% inhibition) reduced growth of the pathogen $(P \leq 0.05$; Figure $4 \mathrm{~A})$. When the isolates were tested against E. lata, all but the Aureobasidium isolates reduced radial growth. The Trichoderma isolates UCD 8368 and UCD 8717 exhibited the greatest VOC effects, both causing at least $50 \%$ growth inhibition, while the Bacillus isolates UCD 8745 and UCD 8347 caused, respectively, approx. 37\% and $39 \%$ inhibition $(P \leq 0.05$; Figure $4 \mathrm{~B})$. None of the isolates exhibited any VOC mediated inhibition of $D$. seriata (Figure 7C). However, against Dia. ampelina, all isolates gave VOC mediated inhibition, with UCD 8717 causing approx. 70\% inhibition. Trichoderma isolate, UCD 8368 caused approx. $40 \%$ inhibition, while the Bacillus isolates UCD 8745 and UCD 8347 and the Aureobasidium isolates UCD 8189 and UCD 8344 all caused approx. $20 \%$ inhibition ( $\leq 0.05$; Figures $4 \mathrm{D}$ and 5$)$.

\section{Multilocus phylogenetic analyses of antagonistic isolates}

Multilocus phylogenetic analysis of the ITS and b1-tubulin genes showed that isolates UCD 8344 and UCD 8189 were most closely related to Aureobasidium pullulans (Figure 6). Analysis of the purH and rpoB genes showed that isolates UCD 8347 and UCD 8745 were most closely related to Bacillus velezensis (Figure 7). Analysis of the ITS and TEF-1a genes showed that 


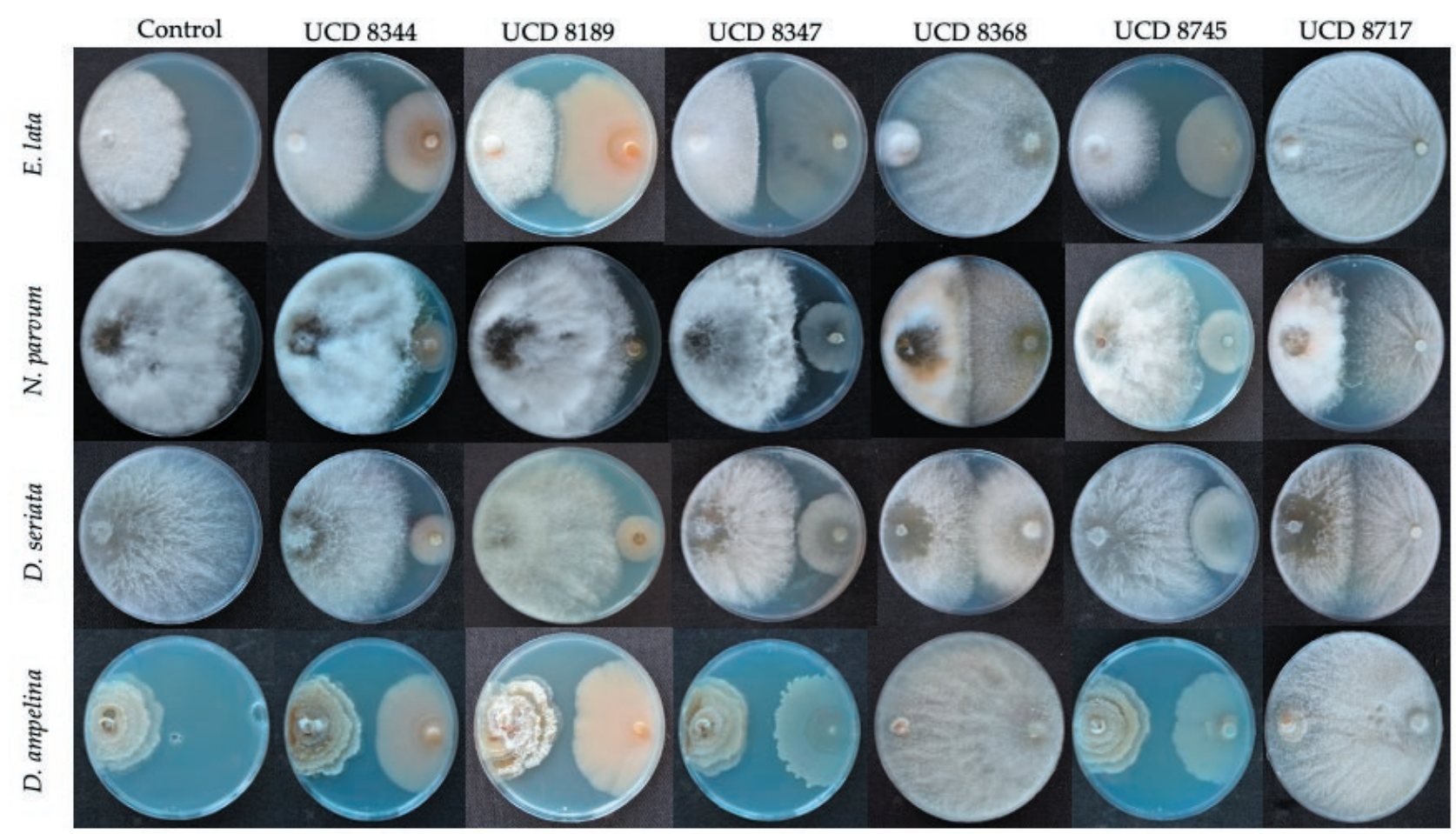

Figure 3. Representative visual summary of in vitro dual culture evaluation of selected isolates ability to inhibit radial mycelial growth of selected grapevine trunk disease pathogens.

A

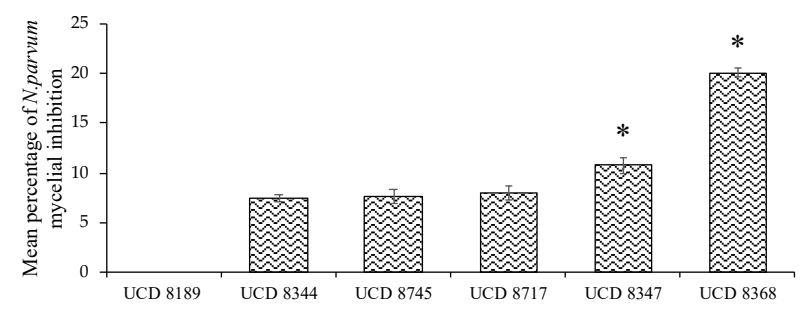

$\mathrm{C}$

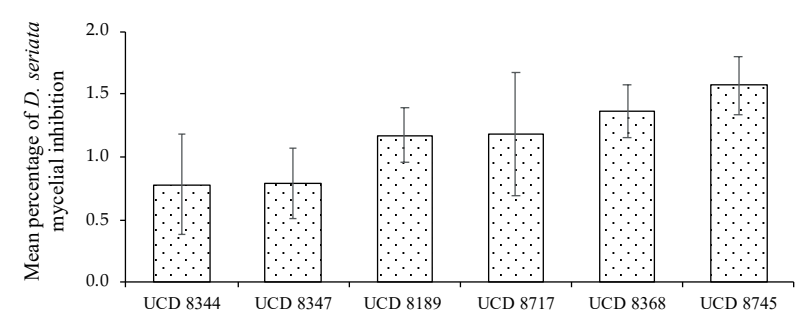

B

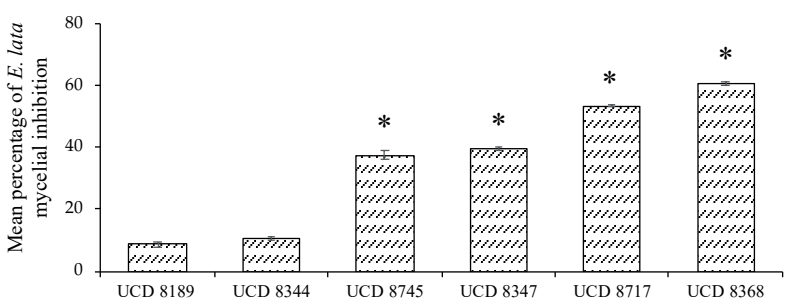

D

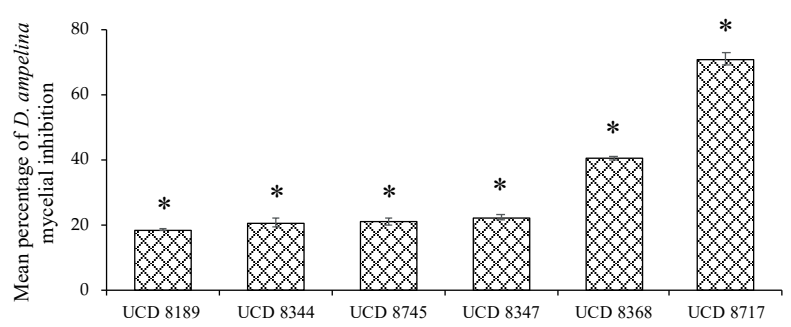

Figure 4. Mean proportions (\%) of inhibition of radial mycelium growth of the grapevine trunk disease pathogens (A) Neofusicoccum parvum, (B) Eutypa lata, (C) Diplodia seriata and (D) Diaporthe ampelina in assays for volatile organic compound using the sealed-baseplates method with modifications. Values are means $\left( \pm\right.$ standard errors) of ten replicates. ${ }^{\star}$ indicates inhibition in comparison with controls (Dunnett's test; $P \leq 0.05$ ). 


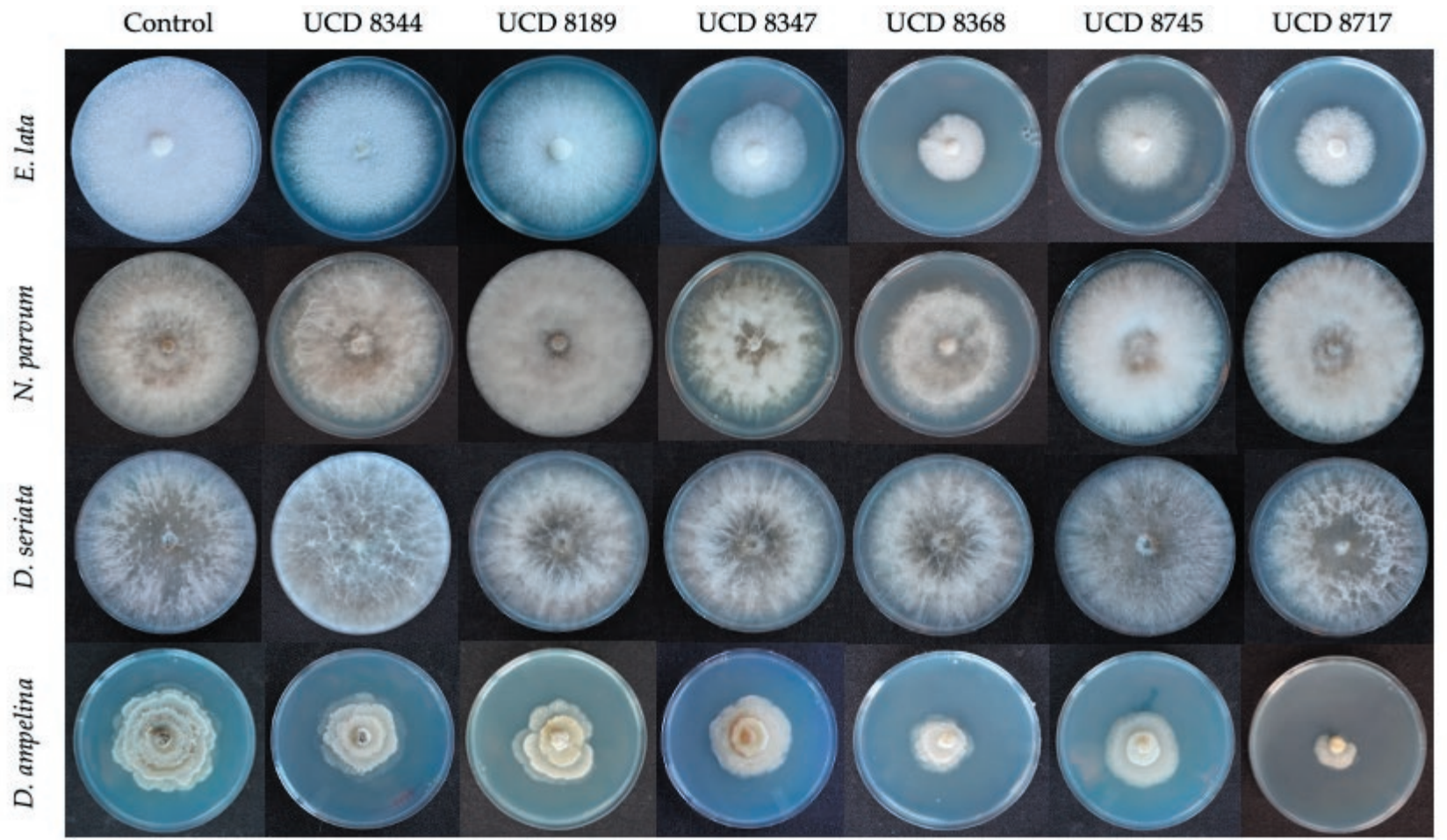

Figure 5. Representative summary of in vitro volatile evaluation of abilities of selected microorganisms (columns of culture) to inhibit radial mycelium growth of four grapevine trunk disease pathogens (rows of cultures).

isolates UCD 8368 was most closely related to Trichoderma asperellum, and UCD 8717 to Trichoderma hamatum (Figure 8).

\section{DISCUSSION}

Grapevine pruning wound protection has historically been mediated using synthetic chemicals which have dominated the crop protection industry since the 1980s. However, sustainability of crop production requires a shift towards low pesticide strategies, so there is increasing interest in novel solutions to prevent and control GTDs (Mondello et al., 2018). Biological control agents including Trichoderma spp. and Bacillus spp. have been shown in vitro to have potential for pruning wound protection against infections from GTDs (Schmidt et al., 2001; Di Marco et al., 2002; 2004; John et al., 2008; Halleen et al., 2010; Kotze et al., 2011; Rezgui et al., 2016). However, microbial inhabitants of nutrient rich grapevine sap have not been previously evaluated for BCA ability against GTDs, so along with microbes isolated from grapevine pith and cane tissues, the present study evaluated microbes for in vitro activity against the GTD pathogens N. parvum, E. lata, D. seriata and Dia. ampelina.
In vitro dual culture assays are the primary means to detect antagonistic activity of microorganisms ( $\mathrm{Di}$ Marco et al., 2002; Haidar et al., 2016). Both Trichoderma isolates UCD 8368 and UCD 8717 in this study exhibited mycelium growth inhibition against all the tested pathogens in dual culture assays, exhibiting at least $75 \%$ inhibition against the slow growing pathogens, E. lata and Dia. ampelina (Figures $1 \mathrm{~B}$ and $2 \mathrm{~B}$ ). Isolate UCD 8368, which is closely related to T. harzianum (Figure 8) was also shown to similarly reduce in vitro growth of E. lata (Úrbez-Torres et al., 2020). Whilst Trichoderma spp. possess various antifungal mechanisms, this mycelium inhibition was likely attributed to overgrowth (Kotze et al., 2011), as the assessed isolates grew more rapidly and surrounded the pathogens in dual cultures (Figure 3). These results are similar to those from other studies, where Trichoderma spp. have been subjected to dual culture assays against $N$. parvum, D. seriata and E. lata (Mutawila et al., 2015; Silva-Valderrama et al., 2020; Úrbez-Torres et al., 2020). For example, Trichoderma isolates from Southern Italy inhibited N. parvum radial growth by up to $74 \%$ (Úrbez-Torres et al., 2020). It is hypothesized that this observed overgrowth by Trichoderma spp. translates to competition for space and nutrients in 


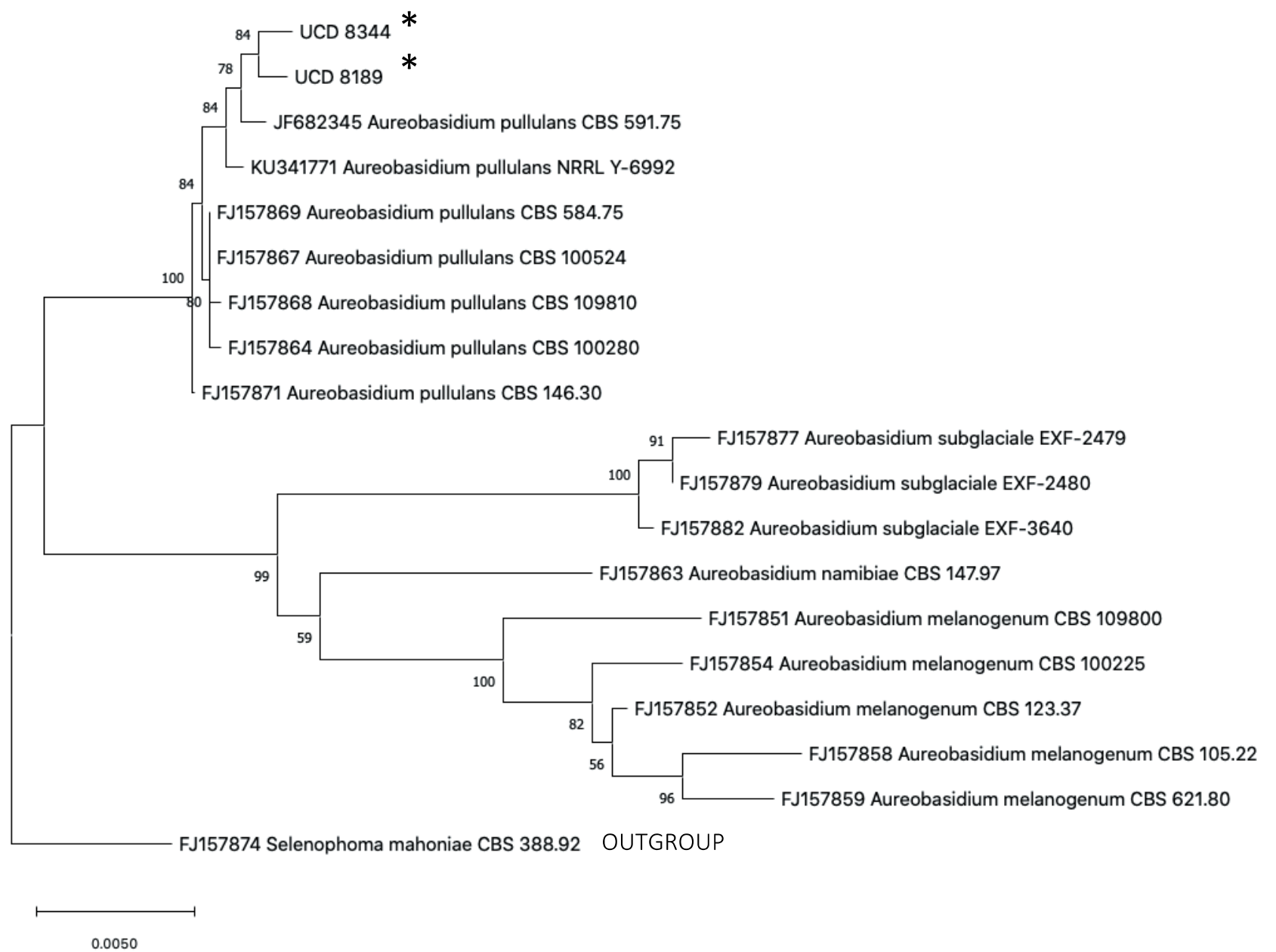

Figure 6. Maximum parsimony phylogenetic tree for isolates UCD 8344 and UCD 8189 based on a multigene data set of internal transcribed spacer rDNA (ITS) and b1-tubulin. Bootstrap support for the maximum-likelihood analysis is given at each node (1000 replicates). * indicates isolates evaluated in the present study. Selenopoma mahoniae FJ150872 was used as an outgroup.

grapevine pruning wounds as a mechanism to protect against GTDs (Úrbez-Torres et al., 2020).

In the volatile assay, isolates UCD 8368 and UCD 8717 were still able to inhibit E. lata and Dia. ampelina (Figure $4 \mathrm{~B}$ and D), which was probably due to the ability of Trichoderma spp. to produce volatile and non-volatile substances which have been shown to inhibit a range of fungi (Chambers and Scott, 1995; John et al., 2004; Kexiang et al., 2002; Kucuk and Kivanc, 2004). John et al. (2004) showed that volatile compounds synthesized by $T$. harzianum AG1, AG2, and AG3 were inhibited growth of $E$. lata, and growth was completely inhibited by nonvolatile compounds. In the present study, isolates UCD8368 and UCD 8717 elicited a coconut odour which has previously been characterized as 6-n-pentyl-2H-pyran2-one (Claydon et al., 1987), and reported to inhibit fungi including Rhizoctonia solani. The inhibition of N. par- vum and $D$. seriata mycelium growth by isolates UCD 8368 and UCD 8717 in dual culture assays can likely be attributed to growth cessation, when microorganism and pathogens grow until they came in contact with one another and growth of both organisms ceases (Kotze et al., 2011) (Figures 1A, 2A and 3). This mechanism as the primary method of inhibition was also indicated by the volatile assays because there was no inhibition of $N$. parvum and D. seriata by isolates UCD 8368 and UCD 8717 (Figures 4A, 4C and 5). The mycoparasitic reactions such as hyphal coiling, adhesion and penetration (Dos Reis Almeida et al., 2007) have been shown to coincide with physical contact interactions; overgrowth and ceased growth. With isolate UCD 8717 being isolated from grapevine sap, this is the first report of a grapevine sap inhabiting microbe showing promising BCA in vitro activity against GTDs. Deyett and Rolshausen (2019) 


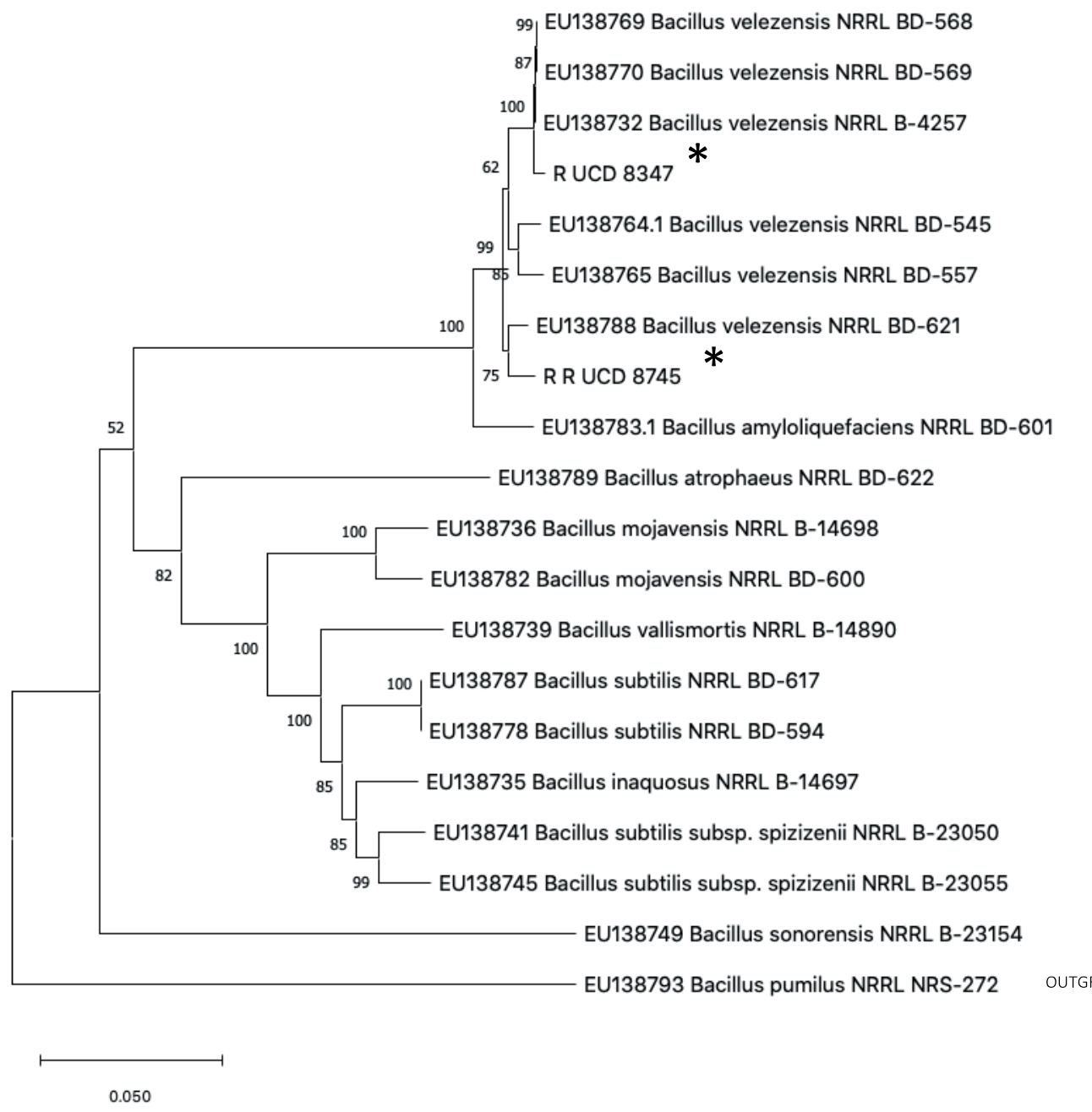

Figure 7. Maximum parsimony phylogenetic tree for isolates of UCD 8347 and UCD 8745 based on a multigene data set of purine biosynthesis $(p u r H)$ and RNA polymerase subunit B $(r p o B)$. Bootstrap support for the maximum-likelihood analysis is given at each node (1000 replicates). ${ }^{*}$ indicates isolates evaluated in this study. Bacillus pumilus EU138793 was used as an outgroup.

utilized a culture-independent amplicon metagenomic approach to characterize the major bacterial and fungal taxa that comprise grapevine xylem sap microbial communities. They showed that the core microbiome consisted of seven bacterial and five fungal taxa. Grapevine sap is a rich source of glucose, fructose and amino acids, especially in spring, when these nutrients are remobilized to the vegetative parts of grapevines following winter dormancy, providing conducive environments to harbour beneficial microbes (Deyett and Rolshausen, 2019).

The bacterial isolates (Bacillus spp.) UCD 8347 and UCD 8745 exhibited varying antifungal ability and mechanisms in this study, depending on the GTD fungal pathogen. In the dual culture assays between UCD 8347 and E. lata, zones of inhibition were observed (Figure 3). Inhibition zones are most likely indicative of antibiotic production (Kotze, 2004) as a mechanism of mycoparasitism. Ferreira et al., (1991) identified at least two Bacillus isolates that produced antibiotic substances responsible for the inhibition of mycelium growth and ascospore germination. Kotze (2011) dual incubated (in vitro) E. lata with the same isolate and showed that the pathogen displayed little mycelium growth and clear inhibition zones between the cultures. Malformation of the hyphae, specifically swelling, was observed. Kotze (2011) showed that a Bacillus subtilis isolate gave clear zones of inhibition against Phomopsis viticola. In an assay for volatiles, isolate UCD 8347 inhibited E. lata, indicating that the antibiotic substance may have been volatile. Isolate UCD 8347 also gave small zones of inhibition against $N$. parvum in the dual culture assays (Figure 3), and slightly inhibited (by $10 \%$ ) growth of $N$. parvum.in the assay for 


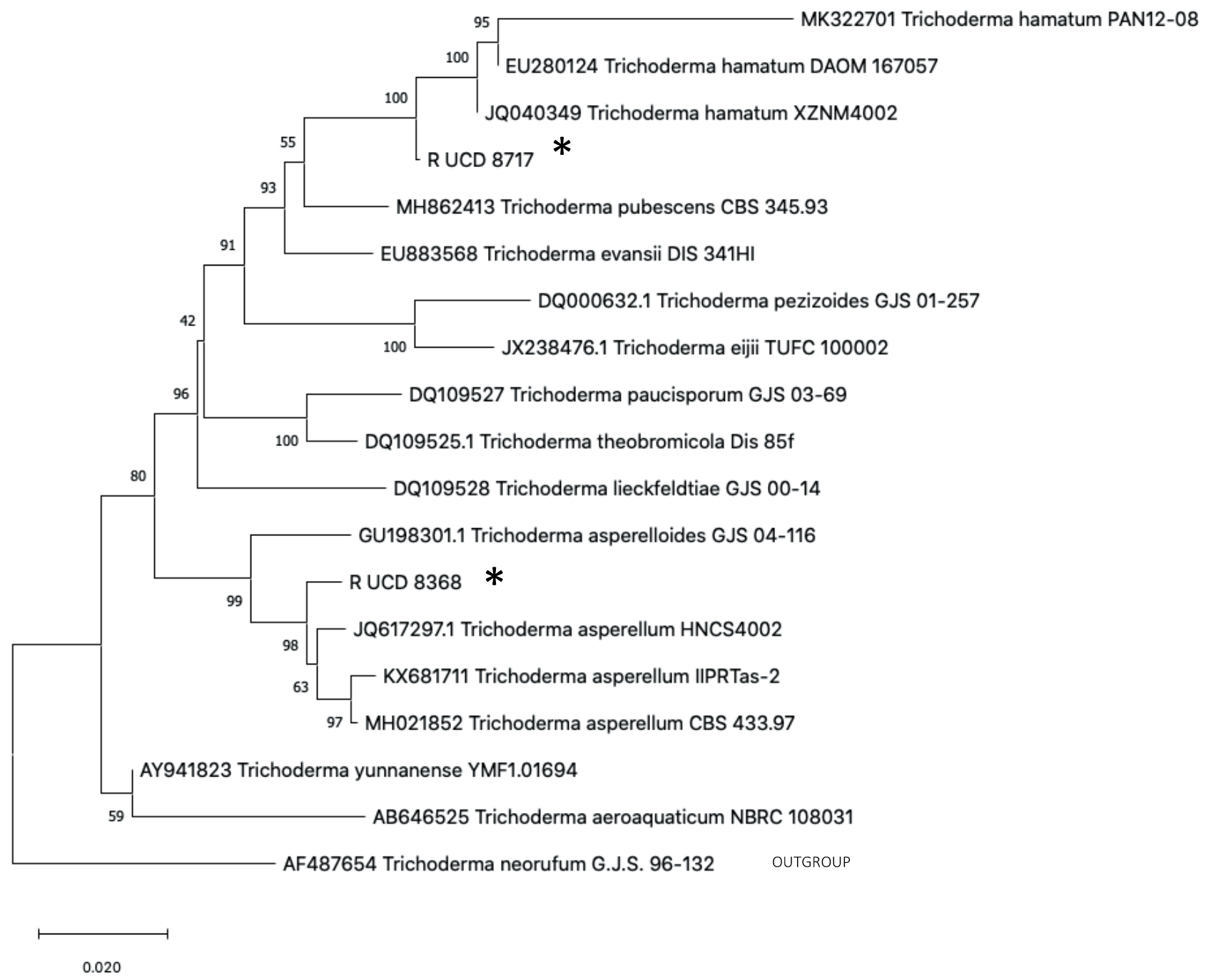

Figure 8. Maximum parsimony phylogenetic tree for isolates UCD 8368 and UCD 8717 based on a multigene alignment of the Trichoderma Hamatum/Asperellum clade using internal transcribed spacer rDNA (ITS), and translation elongation factor 1-alpha (TEF1). Bootstrap support for the maximum-likelihood analysis is given at each node (1000 replicates). ${ }^{*}$ indicates subcultures evaluated in this study. Trichoderma neorufum AF487654 was used as an outgroup.

volatiles, indicating the antibiotic substance may be a volatile product (Figure 4A). Isolate UCD 8347 also gave inhibition of D. seriata and Dia. ampelina in the dual culture assay (Figure 2A and B), and of Dia. ampelina in the volatile assays (Figure 4D) but the mechanism of inhibition was unclear. Isolate UCD 8745 gave similar results to isolate UCD 8347 , although with less inhibition in some assays, and the mechanism of inhibition is not as clear. Subsequent studies should investigate the VOC profiles of these isolates.

Studies of grapevine microbiomes have shown that A. pullulans is commonly distributed in grapevines, both in below and above ground structures (Sabate et al., 2002; Martini et al., 2009; Grube et al., 2011; Barata et al., 2012; Pinto et al., 2014), so A. pullulans has promise as a potential BCA. In the present study, the Aureobasidium isolates UCD 8344 and UCD 8189 showed no antagonistic ability against $N$. parvum, E. lata or Dia. ampelina in dual culture assays, but these isolates inhibited mycelium growth of $D$. seriata in dual cultures (Figure 2A). This was probably due to ceased growth as these two isolates did not inhibit $D$. seriata in the VOC assays (Figure 4C). Similar results were obtained by Pinto et al. (2018), where A. pullulans strain Fito_F278 reduced mycelium growth of $D$. seriata F98.1 in a dual culture assay, and was postulated cause ceased growth of the pathogen.

Although different types of microorganisms were tested in the present study, only Trichoderma spp. have 
been shown to be the most suitable agents for biological control of GTDs. This probably stems from the synergistic actions of different Trichoderma spp. biocontrol mechanisms, their ecological characteristics (saprotrophic, endophytic), and their positive effects induced on their host plants. Grapevines accommodate large pools of resident microorganisms embedded in complex micro-ecosystems (Pinto and Gomes, 2016), so further attempts should be made to identify novel strains of Trichoderma and other microorganisms to promote advances in GTD management.

With the need to make agricultural practices as sustainable as possible, novel solutions for GTD management are required, so that high quality grapes are produced that comply with the high standards of food safety. While in vitro BCA efficacy does not always translate to efficacy in planta, these microbes are the most promising, sustainable option for grapevine growers, because of restrictions and concerns with using chemical fungicides for disease control. The present study has identified potential BCAs with potential for simultaneous control of economically important pathogens responsible for GTDs, and has indicated that further studies to characterize BCA modes of antagonism and evaluate their efficacy in field trials. These potential BCAs may provide long lasting protection of grapevines against GTDs because they share the same host as the important GTD pathogens.

\section{ACKNOWLEDGEMENTS}

This research received funding from the American Vineyard Foundation.

\section{LITERATURE CITED}

Aroca A., Gramaje D., Armengol J., Jose G.-J., Rapaso R., 2010. Evaluation of the grapevine nursery propagation process as a source of Phaeoacremonium spp. and Phaeomoniella chlamydospora and occurrence of trunk disease pathogens in rootstock mother vines in Spain. European Journal of Plant Pathology 126: 165174.

Barata A., Malfeito-Ferreira M., Loureiro V., 2012. The microbial ecology of wine grape berries. International Journal of Food Microbiology 153: 243-259.

Bertsch C., Ramirez-Suero M., Magnin-Robert M., Larignon P., Chong J., Fontaine F., 2013. Grapevine trunk diseases: complex and still poorly understood. Plant Pathology 62: 243-265.
Billones-Baaijens R., Jones E. E., Ridgway H. J., Jaspers M. V., 2013. Virulence Affected by Assay Parameters during Grapevine Pathogenicity Studies with Botryosphaeriaceae Nursery Isolates. Plant Pathology 62: 1214-25.

Bruisson, S., Zufferey, M., L'haridon, F., Trutmann, E., Anand, A., Weisskopf, L., 2019. Endophytes and Epiphytes From the Grapevine Leaf Microbiome as Potential Biocontrol Agents Against Phytopathogens. Frontiers in Microbiology 10: 1-17.

Carbone I., Kohn L. M., 1999. A method for designing primer sets for speciation studies in filamentous ascomycetes. Mycologia 91: 553-556.

Cawoy H., Bettiol W., Fickers P., Ongena M., 2011. Bacillus-based biological control of plant diseases, pesticides in the modern world. In: Pesticides in the Modern World-Pesticides Use and Management (Stoytcheva, M, ed.), Intech: 273-283.

Chambers, S., Scott E., 1995. In vitro antagonism of Phytophthora cinnamomi and P. citricola by Trichoderma species and Gliocladium virens. Journal of Phytopathology 143: 471-477.

Choudray D. K., Johri B. N., 2009. Interactions of Bacillus spp. and plants - With special reference to induced systemic resistance (ISR). Microbiological Research 164: 593-513.

Claydon, N., Allan, M.; Hanson, J. R., Avent, A. G., 1987. Antifungal alkyl pyrones of Trichoderma harzianum. Transactions of the British Mycological Society 88: 503-513.

Deyett, E., Rolshausen, P. E., Temporal Dynamics of the Sap Microbiome of Grapevine Under High Pierce's Disease Pressure. 2019. Frontiers in Plant Science 10: 1-15.

Di Marco, S., Osti, F., Roberti, R., Calzarano, F., Cesari, A., 2002. Attivita' di specie di Trichoderma nei confronti di Phaeomoniella chlamydospora, patogeno associato al mal delll'esca della vite. Atti Giornate Fitopatologiche 419-424.

Di Marco, S., Osti, F., Cesari, A., 2004. Experiments on the control of esca by Trichoderma. Phytopathologia Mediterranea 43: 108-115.

dos Reis Almeida, F. B., Cerqueira, F. M., Do Nascimento Silva, R., Ulhoa, C. J., Lima, A. L., 2007. Mycoparasitism studies of Trichoderma harzianum strains against Rhizoctonia solani: evaluation of coiling and hydrolytic enzyme production. Biotechnology Letters 29(8): 1189-93.

Ferreira, J. H. S., Matthee, F. N., Thomas, A. C., 1991. Biological Control of Eutypa lata on Grapevine by an Antagonistic Strain of Bacillus subtilis. Ecology and Epidemiology 81: 283-287. 
Gilbert, J. A., Van der Lelie, D., Zarraonaindia, I., 2014. Microbial terroir for wine grapes. PNAS 111: 5-6.

Glass, N. L., Donaldson, G. C., 1995. Development of Primer Sets Designed for Use with the PCR To Amplify Conserved Genes from Filamentous Ascomycetes. Applied and Environmental Microbiology 61: 1323-1330.

Gotor-Vila, A., Teixado, N., Di Francesco, A., Usall, J., Ugolini, L., Torres, R., Mari, M., 2017. Antifungal effect of volatile organic compounds produced by Bacillus amyloliquefaciens CPA-8 against fruit pathogen decays of cherry. Food Microbiology 64: 219-225.

Gramaje, D., Armengol, J., 2011. Fungal Trunk Pathogens in the Grapevine Propagation Process: Potential Inoculum Sources, Detection, Identification, and Management Strategies. Plant Disease 95: 1040-1055.

Gramaje, D., Úrbez-Torres, J. R., Sosnowski, M. R., 2018. Managing Grapevine Trunk Diseases With Respect to Etiology and Epidemiology: Current Strategies and Future Prospects. Plant Disease 102: 12-39.

Grube, M., Schmid, F., Berg, G., 2011 Black fungi and associated bacterial communities in the phyllosphere of grapevine. Fungal Biology 115: 978-986.

Gubler, W. D., Rolshausen, P. E., Trouillas, F. P., ÚrbezTorres, J. R., Voegel, T., 2005. Grapevine trunk diseases in California. Practical Winery and Vineyard.

Haidar, R., Deschamps, A., Roudet, J., Calvo-Garrido, C., Bruez, E., Rey, P., Fermaud, M., 2016. Multi-organ screening of efficient bacterial control agents against two major pathogens of grapevine. Biological Control 92: 55-65.

Halleen, F; Crous, P.; Petrini, O. 2003. Fungi associated with healthy grapevine cuttings in nurseries, with special reference to pathogens involved in the decline of young vines. Australasian Plant Pathology 32: 47-52.

Halleen, F., Fourie, P. H., Lombard, P. J., 2010. Protection of grapevine pruning wounds against Eutypa lata by biological and chemical methods. South African Journal for Enology and Viticulture 31: 125-132.

Hardoim, P. R., Can Overbeek, L. S., Berg, G., Pirttila, A. M., Compant, S., Sessitsch, A., 2015. The hidden world within plants: ecological and evolutionary considerations for defining functioning of microbial endophytes. Microbiology and Molecular. Biology Reviews 79: 293-320.

Harman, G. E., 2006. Overview of Mechanisms and Uses of Trichoderma spp. Phytopathology 96: 190-194.

Heimpel, G. E., Mills, N., 2017. Biological Control - Ecology and Applications. Cambridge University Press, Cambridge, UK, 1 pp.

Idris, H. A., Labuschagne, N., Korsten, L., 2007. Screening rhizobacteria for biological control of Fusarium root and crown rot of sorghum in Ethiopia. Biological Control 40: 97-106.

John, S., Scott, E., Wicks, T. J., Hunt, J., 2004 Interactions between Eutypa lata and Trichoderma harzianum. Phytopathologia Mediterranea 43: 95-104.

John, S., Wicks, T. J., Hunt, J., Lorimer, M., Oakey, H., Scott, E. S., 2005. Protection of grapevine pruning wounds from infection by Eutypa lata using Trichoderma harzianum and Fusarium lateritium. Australasian Plant Pathology 34: 569.

John, S., Wicks, T. J., Hunt, J. S., Scott, E. S., 2008. Colonisation of grapevine wood by Trichoderma harzianum and Eutypa lata. Australian Journal of Grape and Wine Research 14: 18-24.

Kaplan, J., Travadon., R., Cooper, M., Hilis, V., Lubell, M., Baumgartner, K., 2016. Identifying economic hurdles to early adoption of preventative practices: The case of trunk diseases in California winegrape vineyards. Wine Economics and Policy 5: 127-141.

Kexiang, G., Xiaoguang, L., Yonghong, L., Tianbo, Z., Shuliang, W., 2002. Potential of Trichoderma harzianum and T. atroviride to control Botryosphaeria berengeriana $\mathrm{f}$. $\mathrm{sp}$. piricola, the cause of apple ring rot. Journal of Phytopathology 150: 271-276.

Kotze, C., Van Niekerk, J., Mostert, L., Halleen, F., Fourie, P., 2011. Evaluation of biocontrol agents for grapevine pruning wound protection against trunk pathogen infection. Phytopathologia Mediterranea 50: 247-263.

Kucuk, C., Kivanc, M., 2004. In Vitro Antifungal Activity of Strains of Trichoderma harzianum. Turkish Journal of Biology 28: 111-115.

Lu, J. J., Perng, C. L., Lee, S. Y., Wan, C. C., 2000. Use of PCR with Universal Primers and Restriction Endonuclease Digestions for Detection and Identification of Common Bacterial Pathogens in Cerebrospinal Fluid. Journal of Clinical Microbiology 38: 2076-2080.

Luque, J., Elena, G., Garcia-Figueres, F., Reyes, J., Barrios, G., Legorburu, F.J., 2014. Natural infections of pruning wounds by fungal trunk pathogens in mature grapevines in Catalonia (Northeast Spain). Australian Journal of Grape and Wine Research 20: 134-143.

Martinez-Diz, M. D. P., Diaz-Losada, E., Andres-Sodupe, M., Bujanda, R., Maldonadao-Gonzalez, M. M., Gramaje, D., 2020. Field evaluation of biocontrol agents against black-foot and Petri diseases of grapevine. Pest Management. Science.

Martini, M., Musetti, R., Grisan, R., Polizzotto, R., Borselli, S., Pavan, F., Osler, R., 2009. DNA-dependent detection of the grapevine fungal endophytes Aureobasidium pullulans and Epicoccum nigrum. Plant Disease 93: 993-998. 
Mondello, V., Songy, A., Battison, E., Pinto, C., Coppin, C., Fontaine, F., 2018. Grapevine Trunk Diseases: A Review of Fifteen Years of Trials for Their Control with Chemicals and Biocontrol Agents. Plant Disease 102: 1189-1217.

Mugnai, L., Graniti, A., Surico, G., 1999. Esca (black measles) and brown wood-streaking: two old and elusive diseases of grapevines. Plant Disease 83: 404418.

Mukherjee, P. K., Horwitz, B. A., Herrera-Estrella, A., Schmoll, M., Kenerley, C. M., 2013. Trichoderma Research in the Genome Era. Annual. Review of Phytopathology 51: 105-129.

Munkvold, G., Duthie, J., Marois, J., 1994. Reductions in yield and vegetative growth of grapevines due to Euytpa dieback. Phytopathology 84: 186-192.

Mutawila, C., Halleen, F., Mostert, L., 2015. Development of benzimidazole resistant Trichoderma strains for the integration of chemical and biocontrol methods of grapevine pruning wound protection. BioControl 60: 387-399.

Otoguro, M., Suzuki, S., 2018. Status and future of disease protection and grape berry quality alteration by micro-organisms in viticulture. Letters in Applied Microbiology 67: 106-112.

Pascoe, I., Cottral, E., 2000. Developments in grapevine trunk diseases research in Australia. Phytopathologia Mediterranea 39: 68-75.

Pinto, C., Pinho, D., Sousa, S., Pinheiro, M., Egas, C., Gomes, A. C., 2014. Unravelling the diversity of grapevine microbiome. PLoS One 9(1).

Pinto, C., Gomes, A. C., 2016. Vitis vinifera microbiome: from basic research to technological development. BioControl 61: 243-256.

Pinto, C., Custodio, V., Nunes, M., Songy, A., Rabenoelina, F., Fontaine, F., 2018. Understand the Potential Role of Aureobasidium pullulans, a Resident Microorganism From Grapevine, to Prevent the Infection Caused by Diplodia seriata. Frontiers in Microbiology 9: 1-15.

Pitt, W. M., Huang, R., Steel, C. C., Savocchia, S., 2013. Pathogenicity and epidemiology of Botryosphaeriaceae species isolated from grapevines in Australia. Australasian Plant Pathology 42: 573-582.

Pitt, W. M., Úrbez-Torres, J. R., Trouillas, F. P., 2015. Dothiorella and Spencermartinsia, new species and records from grapevines in Australia. Australasian Plant Pathology 44: 43-56.

Rezgui, A., Ghnava-Chakroun, A., Vallance, J., Bruez, E. and Hajlaoui, M. R. 2016. Endophytic bacteria with antagonistic traits inhibit the wood tissues of grapevines from Tunisian vineyards. Biological Control 99: 28-37.
Rolshausen, P. E., Akgul, D. S., Perez, R., Eskalen, A., Gispert, C., 2013. First report of wood canker caused by Neoscytalidium dimidiatum on grapevine in California. Plant Disease 97: 1511.

Rolshausen, P. E., Baumgartner, K., Travadaon, R., Fujiyoshi, P., Pouzoulet, J., Wilcox, W. F., 2014. Identification of Eutypa spp. Causing Eutypa dieback of grapevine in eastern North America. Plant Disease 98: 483-491.

Rooney, A. P., Price, N. P. J., Erhardt, C., Swezey, J. L., Bannan, J. D., 2009. Phylogeny and molecular taxonomy of the Bacillus subtilis species complex and description of Bacillus subtilis subsp. inaquosorum subsp. nov. International Journal of Systematic and Evolutionary Microbiology 59: 2429-2435.

Sabate, J., Cano, J., Esteve-Zarzoso, B., Guillamón, J. M., 2002. Isolation and identification of yeasts associated with vineyard and winery by RFLP analysis of ribosomal genes and mitochondrial DNA. Microbiological Research 157: 267-274.

Schmidt, C. S., Lorenz, D., Wolf, G. A., 2001. Biological control of the grapevine dieback fungus Eutypa lata I: Screening of bacterial antagonists. Journal of Phytopathology 149: 427-435.

Siebert, J. B, 2001. Eutypa: the economic toll in vineyards. Wines and Vines 82: 50-56.

Silva-Valderrama, I., Toapanta, D., de los Angeles Miccono, M., Lolas, M., Diaz, G. A., Cantu, D., Castrro, A., 2021. Biocontrol potential of grapevine endophytic and rhyzophtic fungi against trunk pathogens. Frontiers in Microbiology 11.

Strobel, G., Daisy, B., 2003. Bioprospecting for Microbial Endophytes and Their Natural Products. Microbiology and Molecular Biology Reviews 67: 491-502.

Trouillas, F. P., Úrbez-Torres, J. R., Gubler, W. D., 2010. Diversity of diatrypaceous fungi associated with grapevine canker diseases in California. Mycologia 102: 319-336.

Úrbez-Torres, J. R., 2011. The status of Botryosphaeriaceae species infecting grapevines. Phytopathologia $\mathrm{Me}$ diterranea 50: 5-45.

Úrbez-Torres, J. R., Leavitt, T. M., Voegel, T. M., Gubler, W. D., 2006. Identification and distribution of Botryosphaeria spp. associated with grapevine cankers in California. Plant Disease. 90: 1490-1503.

Úrbez-Torres J. R., Tomaselli E., Pollard-Flamand J., Boule J., Gerin D., Pollastro S., 2020. Characterization of Trichoderma isolates from southern Italy, and their potential biocontrol activity against grapevine trunk disease fungi. Phytopathologia Mediterranea 59(3): 425-439.

Waite, H., Morton, L., 2007. Hot Water Treatment, Trunk Diseases and Other Critical Factors in the Produc- 
tion of High-Quality Grapevine Planting Material. Phytopathologia Mediterranea 46: 5-17.

West, E. R., Cother, E. J., Steel, C. C., Ash, G. J., 2010. The characterization and diversity of bacterial endophytes of grapevine. Canadian Journal of Microbiology 56: 209-216.

White, T. J., Bruns, T., Lee, S. W., Taylor, J. W., 1990. Amplification and Direct Sequencing of Fungal Ribosomal RNA Genes for Phylogenetics. In: PCR Protocols: A Guide to Methods and Applications. (M.A. Innis, D.H. Gelfand, J.J. Sninsky, T.J. White, ed.), Academic Press, Cambridge, MA, USA, 317.

Yang, T., Groenewald, Z., Cheewangkoon, R., Jami, F., Abdollahzadeh, J., Crous, P.W., 2017. Families, genera, and species of Botryosphaeriales. Fungal Biology 121: 322-346.

Zanzotto, A., Morroni, M., 2016. Major Biocontrol Studies and Measures Against Fungal and Oomycete Pathogens and Grapevines. In: Biocontrol of Major Grapevine Diseases: Leading Research. (S. Compant, F. Mathieu, ed.), CAB International, Wallingford, UK $1-34$. 